\title{
SANKSI ADAT PADA LARANGAN PERKAWINAN EXOGAMI \\ DI DESA PAKRAMAN TENGANAN PEGRINGSINGAN, DESA TENGANAN, KECAMATAN MANGGIS, KABUPATEN KARANGASEM, PROVINSI BALI
}

\author{
Oleh : \\ I Putu Sudarma \& Pande Putu Toya Wisuda \\ Program Pascasarjana Institut Hindu Dharma Negeri Denpasar \\ E-mail : sudarmaputu@ihdn.ac.id.
}

\begin{abstract}
:
Tenganan Pegrisingan Indigenous Peoples Village, Karangasem, Bali belong to Bali Aga community which is still thick with customary ban on exogamy marriage. Violations of the marriage ban are subject to customary sanctions. Customary sanctions are not only imposed on the bride, but also the parents. Customary sanction on exogamy marriage is motivated by the preservation of tradition and kinship system and balance. In the context of traditional preservation, adat sanctions are used to safeguard, maintain, and preserve endogamy as the most ideal model of marriage. In the context of the kinship system, customary sanctions are used to maintain the purity of lineages in the village. Conversely, in the context of equilibrium, adat sanctions are used for cosmic balance. The impact of adat sanction is exogamy marriage, that is, non-insurrection, does not obtain the welfare of his village, and loses the right of his village. In the context of non-divisiveness, marriage is very closed and limited because its citizens may only engage in endogamous marriage among their own adat folk. In the context of not obtaining the welfare of the village means a violation of endogamy, practically all bridegroom rights including the right to obtain the welfare of his village is lost. In the context of lost rights, all rights are revoked so that the bride has absolutely no rights in his village.
\end{abstract}

Keyword : customary sanctions, prohibitions, exogamy marriages.

\section{Pendahuluan}

Dalam konteks sosial budaya terutama dalam fenomena perkawinan, masyarakat mengenal dua model perkawinan, yaitu model endogami dan eksogami. Menurut Clayton (1975 : 45), ada dua jenis aturan yang berhubungan dengan perkawinan sebagai berikut.

“ (a) Endogamy which refers to rules prescribing that an individual must marry some one within a certain group, and (b) exogamy, which requirest that a person marry some one outside of acertain group".

Model perkawinan endogami mencerminkan preferensi individu kawin dalam kelompok mereka sendiri. Model perkawinan ini telah secara luas dipraktikan di dalam banyak masyarakat dan digunakan dalam berbagai kelompok. Salah satu di antaranya adalah sistem kasta di India yang mengharuskan perkawinan terjadi secara endogami. Pada abad pertengahan di Eropa keluarga raja kawin dengan keluarga raja lainnya. Tidak terkecuali di Amerika Serikat, seorang kulit hitam kawin dengan kulit hitam, orang kulit putih kawin dengan kulit putih. Di pihak lain orang Yahudi menunjukkan preferensi yang sangat kuat untuk kawin dengan sesama orang Yahudi (Sanderson, 1993 : 448-449; Andreski, 1996:92).

Model perkawinan endogami juga pernah berlaku pada zaman kerajaan di Bali. Geertz \& Geertz(2017:198-220), menyebutkan ada empat tipe perkawinan bangsawan di Bali. Pertama, pernikahan endogamy sesama sub dadia (hubungan kekerabatan satu leluhur yang 
garis hubungannya sudah tidak jelas. Kedua, pernikahan eksogami pada sub dadia bangsawan, tetapi tetap dari sub dadia yang sama. Ketiga, pernikahan eksogami antara dadia bangsawan yang tidak ada kaitannya, tetapi mempunyai peringkat yang sama. Keempat, Pernikahan eksogami antara wanita biasa dan bangsawan. Wanita biasa yang menikah dengan bangsawan di Bali akan mendapat titel khusus yakni mekel atau jro. Sebaliknya, wanita bangsawan yang menikah dengan pria dari keluarga biasa dianggap melanggar hukum. Pada zaman prakolonialisme kedua memepelai dikenai hukuman mati. Korn (2017:339) menyatakan bahwa pelanggaran atas larangan perkawinan ini dikenakan sanksi adat asupundung dan alangkahi karang hulu. Asupundung adalah delik adat perkawinan antara perempuan brahmanawangsa dan laki-laki sudrawangsa. Sebaliknya, alangkahi karang hulu adalah sanksi adat perkawinan antara perempuan kesatriawangsa dan laki-laki sudrawangsa. Menurut Krepun (Wiana, 2006 :161-162), semua perkawinan antara perempuan berkasta lebih tinggi dengan laki-laki berkasta lebih rendah di Bali dihukum mati dengan hukuman labuh batu, dan labuh geni. menyatakan bahwa jika terjadi perkawinan antara perempuan yang berkasta lebih tinggi dengan laki-laki yang berkasta lebih rendah, kedua mempelai dihukum mati dengan hukuman labuh geni dan labuh batu. Labuh geni adalah hukuman mati dengan cara membakar hiduphidup mempelai perempuan, sedangkan labuh batu adalah hukuman mati untuk mempelai lakilaki dengan menenggelamkannya ke laut setelah kakinya diberikan pemberat batu hingga tewas. Friederich (1959 : 101-102) dalam bukunya yang berjudul "The Civilization and Culture of Bali" kekejaman kedua hukuman tersebut sebagai berikut.

".....in Bali,all marriage of high-caste women with men of lower birth (provided they bare acknowledged) are punished with death. The guitly women is burned alive. A hole is made in the ground and with combustibbles, into which the women is cast. This punishment is called labuh geni (to faal or to be cast into the fire). The man is weigted with stone and drowned in the sea. This is called labuh batu. This penalty, especially the burning of the women, is not always carried out so relentlessly. In several cases which came to my knowledge both the man and the women were drowned. In another case, where the man had escaped vengeance by flight. The women, at the command of the father (a Gusti in Kuta), was killed with the creese by a relation her's brother, after being adorned with flowers and fine clethes, and rendered fearless by opiun and strong drink".

Kutipan di atas menunjukkan bahwa penerapan sanksi adat pada perkawinan antarwangsa tidak selalu dilakukan dengan hukuman labuh gni, tetapi juga dapat dilaksanakan dengan memberikan opium dan minuman keras sebelum dibunuh.

Walaupun pemerintaan kerajaan tidak ada lagi, setelah zaman kemerdekaan unsure kewangsaan masih tetap merupakan struktur di dalam masyarakat Bali. Hak-hak kewangsan dapat dikatakan tidak hanya merupakan hak keperdataan, yaitu menjadi urusan kekerabatan dari wangsa yang bersangkutan, tetapi juga merupakan persoalan adat. Hal itu terjadi karena adat bali masih mengakui keberadaan dan kedudukan sesorang berdasarkan prinsip linggih (kedudukan seseorang dalam masyarakat) dan sesana (kewajiban) (Dharmayuda, 201:41). Akaan tetapi seiring dengan perkembangan zaman, dan meningkatnya peradaban manusia, sanksi adat asupundung dan alangkahi karang hulu, dicabut pada tahun 1951 oleh pemerintah Bali karena dianggap sangat kejam dan biadab. Dengan pencabutan sanksi adat tersebut, perkawingan cenderung lebih terbuka. Artinya, perkawinan tidak hanya terjadi antarwangsa, lintas agama, tetapi juga berbeda kewarganegaraan (Sudarma, 2015:61).

Berbeda dengan Desa Adat Tenganan Pegrisingan, Karangasem bahwa perkawinan eksogami perlakuannya hampir sama dengan perkawinan antarwangsa di Bali. Perlanggaran atas larangan perkawinan eksogami walaupun kedua mempalai sama-sama beragama Hindu, 
dilaksanakan atas dasar saling mencitai, memenuhi peraturanundang-undang perkawinan di Indonesia, tetapi mendapat perlakuan diskriminatif berupa sanksi adat. Sanksi adat yang dikenakan tidak hanya dirasakan oleh kedua mempalai, tetapi juga orang tuanya.

Fenomena perkawinaneksogami di Desa Adat Tenganan Pegringsingan Bali menarik untuk diungkapkan. Pengungkapan diperlukan karena masyarakat desa ini masih menerapkan sanksi adat pada perkawinan eksogami walaupun sanksi tersebut bertentangan dengan hak-hak asasi manusia, ajaran agama, dan undang-undang perkawinan di Indonesia.

\section{Alasan-Alasan Yang Mendorong Penerapan Sanksi Adat Pada Perkawinan Eksogami}

\subsection{Melestarikan Tradisi}

Pulau Bali yang mayoritas penduduknya beragama Hindu memiliki beragam tradisi. Salah satu di antaranya adalah tradisi perkawinan. Covarrubias (2013 :147-161) menyatakan bahwa adat perkawinan tiap-tiap kabupaten di Bali berbeda-beda. Sering yang dianggap biasa di satu desa, tidak terjadi di desa yang lain karena tidak ada aturan umum yang dapat ditegakkan atau diterapkan di seluruh Pulau Bali. Seorang laki-laki tidak terikat secara moral untuk bersetia dengan adat istrinya, sedangkan ketidaksetiaan dari pihak perempuan dianggap suatu kejahatan yang mengerikan. Pada masa lalu dihukum secara sah dengan kematian dari pasangan yang bersalah.

Perkawinan pada era globalisasi di Bali menunjukkan adanya keterbukaan daripada sebelumnya. Perkawinan tidak hanya terjadi antarwangsa, lintas agama, tetapi juga berbeda kewarganegaran. Akan tetapi, berbeda dengan perkawinan di Tenganan Pegringsingan. Masyarakat desa adat ini kental dengan tradisi perkawinan endogami, sedangkan perkawinan eksogami sangat dilarang bahkan dikenai sanksi adat bagi warganya yang melanggar. Dengan penerapan saksi adat, masyarakat Desa Adat Tenganan Pegringsingan masih terkungkung oleh tradisi perkawinan yang bernuansa diskriminatif.
Warganya tidak boleh melakukan perkawinan eksogami kecuali perkawinan endogami antarwarga adatnya sendiri. Warganya khawatir dan takut melakukan perkawinan eksogami karena di desanya terdapat nilai-nilai kultural yang sangat sulit diubahnya. Mereka masih terikat dngan konsepsi yang berakar pada nilainilai budaya tradisional yang menilai perkawinan endogamy sebagai perkawinan yang paling ideal bahkan dianggap perkawinan terhormat. Di desa adat ini hanya warganya melakukan perkawinan endogami yang mempunyai hak istimewa di desa adatnya. Keistimewaan hak dimaksud adalah hak sebagai krama desa. Tanpa menjadi mekrama desa, mereka tidak boleh duduk dalam struktur sosial, mengikuti sangkepan (rapat) di Bale agung untuk ikut membuat keputusan desa. Sebaliknya, dinilai rendah jika melakukan perkawinan eksogami karena semua haknya dicabut termasuk hak untuk tinggal di desa adatnya.

Menurut Timur sebagai mantan kliang (ketua) Desa Adat Tenganan Pegringsingan, tradisi yang lainnya yang harus ditaati warganya sebelum melakukan perkawinan, yaitu maajakajakan dan metruna nyoman. Maajak-ajakan, yakni pendaftaran diri oleh warganya yang baru naik dewasa baik warga yang laki-laki maupun perempuan, untuk ikut dalam metruna nyoman. Metruna nyoman adalah organisasi tradisional pemuda di Desa Adat Tenganan Pegringsingan dengan keanggotaannya terdiri atas warganya yang laki-laki yang belum menikah, sedangkan sekaa daha adalah organisasi hanya bagi warganya yang perempuan. Matruna nyoman, dan sekaa daha wajib dilakukan oleh semua warganya yang belum menikah. Jika di antara warganya melakukan perkawinan, tetapi belum maajak-ajakan dan matruna nyoman, mereka akan dikenai sanksi adat. Sementara pembinaannya dilakukan di asrama selama satu tahun dan waktu pelaksanaannya tiap hari pada malam hari dari pukul 17.00 hingga pukul 19 00. Materi pembinaannya berkaitan dengan berbagai tradisi, peraturan, dan upacara keagamaan di desanya.

Lodri sebagai istri mantan Kliang Desa Tenganan Pegringsingan menyatakan bahwa 
maajak-ajakan dan metruna nyoman menempati peranan penting dalam perkawinan di desanya. Warganya yang belum pernah mengikuti maajakajakan dan metruna nyoman serta masekaa daha, tetapi melakukan perkawinan dianggap melanggar awig-awig desa. Pelanggaran tersebut dikenai sanksi adat yang sama saksinya beratnya dengan pelanggaran atas larangan perkawinan eksogami. Semua hak mempelai dicabut, dan dikeluarkan atau diusir dari desa. Kedua mempelai dianggap telah melanggar awig-awig, dan mengotori palemahan (alam lingkungan) dan pawongan (warga mayarakat). Ketidakseimbangan desa sebagai akibat perkawinan eksogami dapat dikembalikan seperti semula melalui sanksi adat pencabutan semua hak termasuk hak tinggal di desanya. Dengan dikeluarkan dari desa, keletehan yang mengganggu desanya diyakini keseimbangan desa bisa pulih kembali. Senada dengan Lodri, Putu Yudiana sebagai Kepala Desa Tenganan mengatakan bahwa saat mengikuti masa gerhasta (berumah tangga), kedua mempelai tidak sulit beradaptasi dengan pasangan dan keluarganya masing-masing karena mereka telah saling mengenal sejak anak-anak, bersama-sama mengikuti sistem pembelajaran di pasraman, dan bersama-sama ikut dalam organisasi metruna nyoman. Akan tetapi, sangat berbeda jika salah satu di antara mempelai berasal dari luar Desa Pakraman Tenganan Pegringsingan (perkawinan eksogami) yakni mereka sangat sulit beradaptasi dan memahami berbagai tradisi karena tidak pernah mengikuti pembinaan di desa tersebut.

\subsection{Sistem Kekerabatan}

Hidup individu pada masyarakat di dunia hampir semuanya dibagi oleh adat masyarakat ke dalam tingkat-tingkat tertentu. Tingkatantingkatan sepanjang hidup individu dalam antropologi sering disebut stage along the lifecycle. Tingkat-tingkat hidup tersebut, seperti masa bayi, masa penyapihan, masa kanak-kanak, masa remaja, masa pubertet, masa setelah menikah, masa hamil, masa tua dan sebaginya. Salah satu saat peralihan yang terpenting pada life cycle semua manusia di seluruh dunia adalah saat peralihan dari tingkat hidup remaja ke tingkat hidup berkeluarga (perkawinan). Perkawinan tidak hanya mengatur kelakuan seks, tetapi juga mempunyai berbagai fungsi lainnya. Fungsifungsi yang dimaksud, yaitu (1) memberikan ketentuan hak, kewajiban, dan perlindungan kepada anak-anak hasil persetubuhannya. (2) memenuhi kebutuhan manusia akan seorang teman hidup, memenuhi kebutuhan akan harta, dan (3) pemeliharaan hubungan antara kelompokkelompok kerabat (Koentjaraningrat, 1992:9394).

Tiap-tiap bangsa di dunia terdiri atas beraneka ragam suku bangsa, agama, dan hukum adat yang satu dengan yang lainnya berbeda. Hukum adat adalah hukum yang timbul dan terdapat masyarakat. Hukum adat terdiri atas kumpulan norma berisikan kaidah-kaidah hukum yang dibuat dengan sengaja oleh masyarakat. Dengan demikian, hukum adat dapat dipandang sebagai cerminan aspek-aspek kerohanian suatu masyarakat yang berkaitan erat dengan susunan kehidupan masyarakat. Salah satu yang di atur masyarakat adalah tentang sistem kekerabatan. Para ahli menyatakan bahwa paling sedikit ada empat prinsip kekerabatan. Keempat prinsip kekerabatan tersebut, yaitu pertama, prinsip patrilineal (patrilineal descent) adalah kekerabatan yang memperhitungkan hubungan kekerabatan melalui pria saja.Tiap individu dalam masyarakat semua kaum kerabat ayahnya masuk dalam hubungan kerabatanya, sedangkan kerabat ibunya berada di luar batas kerabat tersebut. Kedua, prinsip matrilineal (matrilineal descent) adalah kekerabatan yang memperhitungkan hubungan kekerabatan melalui ibu saja. Tiap individu dalam masyarakat semua kerabat ibunya masuk dalam batas hubungan kekerabatannya, sedangkan semua kaum kerabat ayahnya berada berada di luar batas tersebut. Ketiga, prinsip bilinial (bilinial descent) adalah kekerabatan yang memperhitungkan hubungan kekerabatan melalui pria saja untuk sejumlah hak dan kewajiban tertentu, dan melalui wanita saja untuk sejumlah hak dan kewajiban yang lain. Kempat, prinsip bilateral (bilateral descent) adalah kekerabatan 
yang memperhitungkan hubungan kekerabatan melalui, baik ayah maupun wanita. Semua kaum kerabat, baik ibu maupun ayah masuk dalam hubungan kekerabatannya sehingga tidak ada batas sama sekali (Koentjaraningrat, 1992 : 135).

Budiana (2008 : 11) menyatakan bahwa perkawinan sulit dipahami tanpa memahami sistem kekeluarga kekerabatan. Masyarakat Hindu di Bali sebagaimana masyarakat umumnya di Indonesia, menganut sistem kekerabatan patrilineal. Sistem kekerabatan ini didasari garis keturunan yang ditarik melalui pihak laki-laki. Dengan sistem kekekrabatan patrilineal, peran anak laki-laki sangat penting baik dalam hubungan dengan kekeluargaan maupun dalam hubungan kemasyarakatan. Dalam hubungan kekeluargaan, anak laki-laki berperan sebagai penerus keturunan, hak, dan kewajiban dalam keluarga. Anak lakilaki mempunyai hak mewarisi harta kekayaan orang tuanya dan mempunyai kewajiban dalam pemeliharaan tempat suci keluarga. Kewajiban lainnya adalah melaksanakan upacara pitra yadnya (upacara kematian). Sebaliknya, dalam konteks hubungan kemasyarakatan, peran anak laki-laki tampak lebih menonjol sebagai krama (anggota) di banjar atau desa pakraman.

Di Bali masyarakat tidak dipandang sebagai badan yang terpisah dari individu dan golongan, tetapi merupakan bagian dari masyarakat. Maksudnya, masyarakat mengakui hak-hak individu dan individu mengakui hakhak masyarakat sebagai suatu kepentingan bersama. Dalam sistem nilai masyarakat Bali terdapat pandangan yang menilai tinggi suatu kehidupan jika didasarkan atas asas kebersamaan, asas kekeluargaan, dan asas berbakti. Ketiga asas tersebut bersumber pada pandangan hidup masyarakat bahwa manusia tidak hidup sendiri di dunia, tetapi dikelilingi oleh komunitasnya, masyarakat, dan alam sekitarnya. Asas kebersamaan dapat mendorong manusia untuk berorientasi kepada sesamanya, asas kekeluargaan mendorong manusia mewujudkan persatuan dan kesatuan, serta asas berbakti menumbuhkan loyalitas untuk mengabdi. Rasa bakti masyarakat
Bali diwujudkan dalam bentuk yadnya (korban suci) yang ditujukan ke hadapan Hyang Widhi (Tuhan) (Majelis Pembina Lembaga Adat Daerah Tingkat I Bali, 1992/1993 : 9).

Putu Yudiana sebagai Kepala Desa Tenganan Pegringsingan bahwa masyrakat desa ini tidak mengenal sistem kekerabatan berdasarkan kasta kecuali sistem kekerabatan bilateral. Jika terjadi perkawinan, kedua mempelai berhak menjadi ahli waris. Hak dan kedudukan antara anak laki-laki dan perempuan sama di mata hukum. Dengan sistem kekerabatan ini juga seorang ego mengenal keluarga luas. Maksudnya, seorang ego mengenal hubungan mereka dengan sanak saudara, baik dari pihak ibu maupun pihak ayah. Hubungan kekerabatan desa ini juga menjadi sangat erat karena pihak suami dan istri masih memiliki hubungan darah. Dengan sistem kekerabatan bilateral di Desa Adat Tenganan Pegringsingan menyebabkan kesatuan dan keutuhan kebudayaan tetap terjaga dan terpelihara karena kedua pihak mempelai memiliki tanggung jawab yang sama baik di dalam keluarga maupun masyarakat. Sebaliknya, kekerabatannya dicabut dan hilang di desa ini jika warga adatnya melakukan perkawinan eksogami. Dengan demikian, agar warga tetap menjadi kerabat harus melakukan perkawinan endogami. Jika warga melakukan pelanggaran atas larangan perkawinan eksogami, konskuensinya kekerabatannya hilang karena dicabut oleh desa.

\subsection{Menjaga Keseimbangan}

Manusia dalam hidupnya tidaka hanya sebagai makhluk individu, tetapi juga sebagai makhluk sosial. Dalam kapasitasnya sebagai makhluk sosial, manusia tidak dapat hidup dalam kesendirian tanpa bantuan orang lain sehingga sikap tolong-menolong dan kesetiakawanan sangat dibutuhkan. Hal ini memberikan kewajiban untuk memperhatikan keperluan-keperluan sesamanya. Koentjaraningrat (1992:55) menyatakan bahwa setiap manusia yang hidup dalam masyarakat akan terikat oleh suatu bentuk kesatuan sosial karena adanya ikatan wilayah atau tempat kehidupan. Sebagai suatu kesatuan hukum sosial, warga masyarakat biasanya mempunyai perasaan 
kesatuan yang dapat mewujudkan rasa kepribadian kelompok.

Di Bali masyarakat tidak dipandang sebagai badan yang terpisah dari individu dan golongan, tetapi merupakan bagian dari masyarakat. Maksudnya, masyarakat mengakui hak-hak individu dan individu mengakui hak-hak masyarakat sebagai suatu kepentingan bersama. Masyarakat Bali juga memiliki pandangan yang menilai tinggi suatu kehidupan jika didasarkan atas asas kebersamaan, asas kekeluargaan, dan asas berbakti. Ketiga asas tersebut bersumber pada pandangan hidup masyarakat bahwa manusia tidak hidup sendiri di dunia, tetapi dikelilingi oleh komunitasnya, masyarakat, dan alam sekitarnya. Asaskebersamaan dapat mendorong manusiauntuk berorientasi kepada sesamanya, asas kekeluargaan mendorong manusia mewujudkan persatuan dan kesatuan, serta asas berbakti menumbuhkan loyalitas untuk mengabdi (Majelis Pembina Lembaga Adat Daerah Tingkat I Bali, 1992/1993 : 9). Pandangan hidup masyarakat Bali tersebut juga di Desa Adat Tenganan Pegringsingan yang dipandang dapat menggerakkan dan mewujudkan perbuatan-perbuatan nyata dalam masyarakat berupa tolong-menolong, gotong royong, dan sukaduka dalam kehidupan bermasyarakat.

Setiap kelompok kehidupan manusia mempunyai cara-cara tertentu di dalam mengatur hubungan yang terjadi antara hidup dan kehidupannya dengan tidak membedakan suatu kehidupan bermasyarakat, baik dalam kelompok yang kecil maupun besar. Aturan-aturan hidup di dalam masyarakat harus diterima oleh anggota masyarakat sebagai suatu pembatasan karena kehidupan yang bebas tanpa batas tidak dikenal di dalam kehidupan bermasyarakat. Setiap anggota masyarakat merasa terikat dalam kehidupan bermasyarakat dan diperlukan adanya pembatasan untuk lancarnya kehidupan bermasyarakat dan terselenggaranya kepentingan anggota masyarakat yang satu dengan yang lain. Kesadaran adanya aturan-aturan yang hidup dan mengikat dalam hidup bermasyarakat merupakan syarat agar terciptanya suasana kehidupan yang tertib, aman, dan damai (Tim Penyusun, 1989/1990:19-20).
Di dalam masyarakat, seseorang dikatakan memiliki keseimbagan dalam hidupnya jika melakukan pelanggaran hukum. Suatu perbuatan melangar hukum mengakibatkan keketoran dalam tubuh masyarakat dan keguncangan dalam neraca keseimbangan masyarakat. Bagimanapun kecilnya suatu guncangan, akan membawa keguncangan pada neraca keseimbangan dalam masyarakat. Sedikit banyak keguncangan yang dirasakan sebagai akibat suatu keketoran, mempengaruhi masyarakat seluruhnya (Projodikoro, 2000:1314).

Masyarakat Bali selalu berusaha bersikap seimbang terhadap alam sekitarnya yang dilandasi oleh kesadaran bahwa alam semesta merupakan kompleksitas unsur-unsur yang satu dan yang lainnya mempunyai hubungan yang erat dan membentuk sistem kemestaan. Nilai dasar kehidupan adat di Bali adalah nilai keseimbangan yang terwujud dalam dua unsur, yaitu (1) penyesuaian diri dan berusaha menjalin hubungan dengan elemen-elemen alam dan kehidupan yang mengitari; (2) ingin menciptakan suasana kedamaian dan ketentraman antarmakhluk dan alam tempat manusia hidup. Kedua unsur tersebut digunakan sebagai pedoman masyarakat Bali dalam segala kegiatan hidupnya. Nilai-nilai dan asas tersebut dipersepsikan kedalam ajaran filsafati Tri hita karana (Dharmayudha dan Çantika, 1991 : 6). Sebaliknya, Kaler (1983 : 86) menyatakan bahwa secara harfiah kata tri hita karana berasal dari kata tri, hita dan karana. Tri artinya tiga, hita artinya baik, senang, gembira, lestari, sedangkan karana artinya sebab musabab atau sumbernya sebab. Jadi tri hita karana adalah tiga buah unsur yang merupakan sumbernya sebab timbulnya kebaikan. Ketiga unsur tersebut selalu diusahakan agar terciptanya keseimbangan hubungan manusia dengan Tuhan, antara sesama manusia, dan manusia dengan alam. Upaya menjaga ketiga keseimbangan tersebut dituangkannya dalam awig-awig desa adat.

Hidup bahagia merupakan dambaan setiap orang. Dalam mencapai kebahagiaan hidup, manusia hendakya mengupayakan kondisi yang diajarkan dalam filosofis hidup tri hita karana. 
Hidup bahagia tidak berarti hidup bersenangsenang karena dibalik kebahagiaan ada kedukaaan. Hal ini termuat dalam Kitab Bhagavadgita II.15 sebagai berikut.

Yam hi na vyathayanty ete purusam purusarsabha,

sama dhuka-sukham dhiram so mrtatvaya kalpate,

Artinya :

Orang yang teguh pikirannya adalah orang yang dapat merasakan sama dan sehimbang antara suka dan duka. Orang yang seperti itu patut mendapatkan kehidupan yang kekal abadi (Maswinara, 1997:123).

Kebahagiaan dan kesuksesan merupakan realita dari dinamika kehidupan manusia. Mencari kebahagiaan dan keberhsilan paling banyak menyita berbagai potensi manusia di muka bumi ini. Hiruk pikuk kehidupan manusia dalam mencari kebahagiaan dan keberhasilan perlu dijadikan renungan mendalam sebagai upaya mencari kebahagiaan sesuai dengan filosofis tri hita karana. Jika manusia salah melangkah dalam mencari kebahagiaan dan keberhasilan, keseimbangan akan terganggu. Krisna dalam kitab Bhagavagita menyatakan bahwa kebahgiaan harus dicapai dengan sikap yang teguh, sama, dan seimbang dalam menerima suka dan duka dalam hidup ini seperti tertera dalam syair suci, yaitu "sukhamdhukam jayate" artinya menanglah menghadapi suka dan duka. Tidak dapat dimungkiri bahwa banyak orang gagal dalam hidupnya karena tidak bisa memelihara kesehimbangan diri, dan lupa dalam menerima keberhasilannya (Wiana, 2007:28-29).

Terkait dengan menjaga keseimbangan di Desa Adat Tenganan Pegringsingan salah satu di antaranya warga dilarang melakukan perkawinan eksogami. Menurut Sanjaya sebagai warga masyarakat Tenganan Pegringsingan bahwa pelanggaran atas larangan perkawinan eksogami, diyakini desanya mengalami keletehan karena warganya tidak menaati awig-awig desa adatnya. Keletehan tidak hanyaberkaitan dengan pawongan, tetapi juga palemahan. Dengan pelanggaran awig-awig juga menyebabkan keseimbangan desanya tergamggu. Dalam konteks pawongan, hubungan kekerabatan desanya terganggu karena masyarakat tenganan Pegringsingan tidak mengenal kekerabatan lain, kecuali kekerabatan desa. Selama mempelai tidak dikenai sanksi adat berupa pengusiran dari desanya, mempelai akan selalu menjadi bahan pergunjingan karena melanggar adat istiadat yang berlaku di desanya. Tanpa sanksi adat, ketidakseimbangan akan tetap dirasakan oleh masyarakatnya karena menjadi persoalan adat. Sebaliknya dalam konteks palemahan, perkawinan eksogami diyakini mengotori lingkungan Tenganan Pegringsingan sebagai akibat dari pelanggaran perkawinan eksogami. Dengan demikian, agar keseimbangan palemahan dan pawongan dapat pulih kembali, kedua mempelai harus dikeluarkan dari desanya.

\section{Bentuk Sanksi Dalam Perkawinan Eksoga- mi Di Desa Adat Teganan Pegringsingan}

\subsection{Sanksi Denda}

Masyarakat Tenganan Pegringsingan sampai saat ini masih menganggap bahwa perkawinan endogami merupakan perkawinan yang idial dan terhormat. Sebaliknya, perkawinan eksogami merupakan perkawinan yang tidak baik dan dilarang. Pelanggaran atas larangan perkawinan tersebut mengakibatkan mempelai dan orang tuanya sama-sama dikenai sanksi adat.

Bagi umat Hindu di Bali, istilah "sanksi adat" lebih populer dengan sebutan "pamidanda". Windia (2003 : 29) menyatakan ada tiga jenis pamidanda, yaitu arta denda, sangaskara danda, dan jiwa danda. Artadanda adalah denda dalam wujud materi berupa berbagai benda yang mempunyai nilai ekonomi atau berupa uang. Uang yang dimaksud berupa uang kertas atau uang kepeng. Akan tetapi, pembayaran denda sama sekali belum pernah dilakukan dengan menggunakan cek atau kartu kredit. Dalam danda arta juga dilakukan dengan ayahan panukun kasisipan, yaitu kewajiban untuk melakukan perbuatan tertentu (ngayah) selama waktu tertentu sebagai pengganti atas kewajiban membayar danda materi atau uang. Sangaskara danda adalah sanksi denda 
berupa melaksanakan upacara tertentu. Denda ini dikenakan kepada warga yang melakukan perbuatan tertentu yang dianggap menimbulkan leteh (suatu keadaan yang dianggap suci) seperti pencurian, pembunuhan, dan berbagai tindakan pidana yang lainnya. Perbuatannya tersebut tidak hanya dianggap merugikan secara material tetapi juga menimbulkan ketidakseimbangan batin. Pelaksanaan sangaskara danda berupa upacara prayascita atau upacara pecaruan. Danda sangaskara biasanya juga dibebankan terhadap perbuatan yang dianggap dapat menimbulkan perasaan tidak menyenangkan, seperti mengeluarkan kata-kata kotor, mencaci maki, dan sebagainya. Jiwa danda atau atma danda adalah sanksi yang berkaitan dengan jiwa pelaku yang melakukan pelanggaran. Pada zaman dahulu hukuman ini dilakukan dengan tikaman sebilah keris atau menenggelamkan ke laut bagi yang melanggar. Akan tetapi dewasa ini jiwa danda dapat berupa pengaksama (menyampaikan permintaan maaf) di hadapan paruman (rapat) desa.

Dharmayuda (2001 : 34-37) mengklasifikasikan jenis pamidanda menjadi tujuh macam, yaitu (1) denda arta, ((2) ayahan penukun kesisipan, (3) rerampagan, (4) kedaut karang ayah, (5) penyangaskara, (6) kasepekang, (7) kanoroyang. Di antara berbagai jenis sanksi adat tersebut, sanksi adat pada perkawinan eksogami di Tenganan Pegringsingan adalah sanksi denda arta dan sanksi kanoroyang. Sanksi denda arta jumlah nominalnya sudah ditetapkan pada paos 7 awigawig Desa Adat Tenganan Pegringsingan sebagai berikut.

Mwah tingkah $i$ wong desa ika sinalih tunggal ngasampingang piyanak nyane, wiyadin nyama luh, mwah nyolongang kacolongan, pada tan kawasa, tka wnang kadanda olih desa, gung arta 75.000 mantuk ka desa saungkul.

\section{Terjemahannya :}

Prihal salah seorang warga desanya membiarkan anaknya kawin keluar desa, baik anak perempuan maupun saudara wanitanya atau ikut membantu/memberi kesempatan, sama sekali dilarang, serta didenda oleh desa sebesar 75.000, semuanya diserahkan kepada desa (Desa Adat Tenganan, $t t$ : 90).

Kutipan di atas menunjukkan bahwa sanksi denda yang harus dibayar oleh orang tua mempelai sebanyak 75.000 uang kepeng asli. Dewasa ini di Bali uang kepeng asli per keteng (biji) harganya Rp 3 000,00. Dengan demikian, denda arta yang mesti dibayar oleh orang tua mempelai $\mathrm{Rp} 225$ 000000,00 .

Seiring dengan perkembangan zaman, Timur sebagai mantan Kliang Desa Tenganan Pegringsingan menyatakan bahwa sanksi denda arta atas pelanggaran larangan perkawinan eksogami sudah mengalami perubahan. Artinya, warga yang melanggar larangan perkawinan eksogami tidak lagi membayar Rp 225000 000, 00 tetapi Rp.18 000 000,00. Hal ini dilakukan dengan pertimbangan kemanusiaan, yaitu meringankan beban keluarga mempelai. Di samping itu memepali juga sudah kehilangan semua hak di desanya. Orang tua memepelai juga tiap bulan wajib membayar uang Rp1000,00 kepada desa adat sebagai tanda kesalahan pelanggaran atas larangan perkawinan eksogami.

\subsection{Sanksi Moral}

Setiap gangguan atau benturan terhadap keseimbangan kehidupan orang perorangan atau orang-orang banyak sebagai satu kesatuan dalam ketertiban hukum dianggap sebagai suatu pelanggaran (delik) adat (Ter Haar, 2001:226). Delik adat adalah semua perbuatan atau kejadian yang bertentangan dengan kerukunan, ketertiban, keamanan, rasa keadilan, dan kesadaran masyarakat bersangkutan, baik sebagai akibat dari perbuatan yang dilakukan oleh seseorang, sekolompok orang maupun pengurus adat sendiri. Perbuatan yang melanggar adat dipadang dapat menimbulkan keguncangan sehingga tergganggu kesehimbangan kosmos. Keguncangan dapat menimbulkan reaksi masyarakat berupa sanksi adat (Widnyana, $1993: 6$ ).

Lesqiller dalam disertasinya "Het Adat DelectenrechtindeMagische Wereldbeschouwing" 
sebagaimana dikutip oleh Soeroyo Wignjodipoero menjelaskan bahwa sanksi adat sangat diperlukan untuk mengembalikan ketenteraman magis yang diganggu. Di samping itu juga meniadakan atau menetralisir suatu keadaan sial yang ditimbulkan oleh suatu pelanggaran adat (Tim Penyusun, 2010:76-77). Di pihak lain Sianturi (1986:30) menyatakan bahwa sanksi adat memiliki beberapa fungsi, yaitu (1) sebagai alat pemaksa agar seseorang atau warga mennaati norma-norma yang berlaku, (2) sebagai norma hukum untuk ditaati, dan (3) sebagai akibat hukum bagi seseorang yang melanggar norma hukum. Senada dengan pendapat Sianturi, Çantika mengemukakan bahwa sanksi adat dapat digunakan untuk memulihkan kepada keadaan trepti (tertib), dan sukerta (tenteram) yakni adanya keseimbangan dari sattyam (kebenaran), siwam (kesusilaan), dan sundaram (kebahagiaan) yang terjawantah ke dalam filosofis tri hita karana (tiga penyebab kebahagiaan) (Tim Penyusun, 2010:94-95).

Sanksi adat yang dijatuhkan atas pelanggaran larangan perkawinan eksogami di Desa Adat Tenganan Pegringsingan tidak hanya berupa sanksi denda, tetapi juga sanksi moral. Sanksi moral adalah sanksi batin berupa rasa malu atau rasa bersalah (berdosa) (All-Barry, 2001:292). Covarrubias ( 2013 :69) mengemkakan bahwa sanksi moral di Bali bebannya jauh lebih besar dibandingkan dengan hukuman badan, kesalahankesalahan ringan mengakibatkan denda, dan penyitaan harta benda, atau penundaan sementara dari masyarakat. Akan tetapi, hukuman bagi kesalahan-kesalahan besar bervariasi antara boikot yang menakutkan dari semua kegiatan desa sampai pengucilan tetap, pengusiran sepenuhnya dari desa. Seseorang yang disingkirkan dari desanya tidak diijinkan masuk ke kemunitas lain. Dia benar-benar menjadi terbuang sebagai sebuah hukuman yang jauh lebih berat dari kematian fisik bagi pikiran orang Bali karena seseorang secara terbuka dipermalukan, membunuh dirinya sendiri.

Di antara tujuh sanksi adat di atas, sanksi kanoroyang merupakan sanksi moral yang paling berat pada perkawinan eksogami di Desa Tenganan Pegringsingan. Warga yang dikenai sanksi adat kasepekang saja sudah diangap berat apalagi sanksi kanoroyang. Krama adat yang dijatuhi sanksi kasepekang, statusnya masih tetap diakui sebagai krama adat, tetapi ia ditempatkan di luar tata hukum. Maksudnya, krama yang bersangkutan tidak dikenai aturan hukum adat, seperti tidak mendapatkan pemberitahuan (tan polih arah-arahan), tidak mendapat layanan kentongan (tan polih pasuwaran kulkul), dan tidak mendapat bantuan banjar. Ia juga masih dapat menggunakan kuburan, tetapi tidak mendapatkan bantuan layanan banjar atau desa pakraman. Sebaliknya, dalam sanksi adat kanoroyang, status yang bersangkutan sudah tidak lagi sebagai warga desa pakraman karena tidak hanya dikucilkan, tetapi juga diusir dari desanya. Wayan Koti Cantika membedakan antara sanksi adat kasepekang dan kanoroyang. Dalam sanksi adat kasepekang, seseorang yang dikenai sanksi masih diakui keberadaannya sebagai krama, tetapi dikucilkan dari berbagai aktivitas banjar/ desa pakraman. Sebaliknya, dalam sanksi adat kanoroyang, seseorang tidak saja dikucilkan, tetapi juga dianggap tidak ada (Windia, 2008:5051).

Akibat pelangaran atas larangan perkawinan eksogami di Tenganan Pegringsingan tidak hanya dirasakan oleh mempelai, tetapi juga orang tuanya. Orang tua mempelai harus membayar sejumlah uang, sedangkan sanksi untuk anaknya yang melakukan perkawinan eksogami tidak hanya diusir, tetapi juga kehilngan semua hak-haknya di desa adat tersebut. Sanksi adat ini diputuskan melalui sangkepan (rapat) desa adat yang dihadiri oleh seluruh krama desa adat. Penjatuhan sanksi juga diputuskan secara terbuka dalam forum sangkepan desa adat. Sistem pengambilan keputusan tersebut menimbulkan rasa malu dan rasa berdosa dari pihak keluarga mempelai karena anaknya berperilaku tidak sesuai dengan nilai-nilai, norma-norma, dan aturan-aturan yang berlaku di masyarakatnya terutama berkaitan dengan perkawinan eksogami. Penjatuhan sanksi adat menyebabkan, mempelai sama sekali tidak memiliki hak termasuk hak untuk tinggal di desa adatnya. 


\section{Dampak Sanksi Adat pada Perkawi- nan Eksogami Di Desa Adat Tenganan Pegringsingan}

\subsection{Ketidakemansipasian}

Secara fungsional, adat yang diciptakan dalam suatu sistem sosial masyarakat dimaksudkan agar terjadi suatu order (tertib) sosial di masyarakat. Menurut Comte dan Spencer, masyarakat dipandang sebagai sistem sosial yang terdiri atas bagian-bagian yang saling bergantung satu sama lain (Poloma,1992:25). Oleh karena itu, lembaga adat sebagai salah satu struktur yang ada dalam masyarakat diharapkan dapat memberikan rasa aman dan nyaman sehingga dapat tercipta kehidupan masyarakat yang harmonis.

Masyarakat Bali terorganisisasi dalam organisasi tradisional, yaitu desa adat atau desa pakraman. Surpha (2002,16-17) menyatakan bahwa desa pakraman merupakan institusi yang berfungsi memelihara dan menegakkan adat istiadat yang berlaku di tiap-tiap desa pakraman. Jika terjadi pengingkaran-pengingkaran adat, dipandang sebagai suatu hal yang tercela dan merusak kerukunan hidup krama desa. Untuk mencegah pengingkaran-pengingkaran ini, desa pakraman bertugas menata dan mengatur kehidupan paguyuban warga desanya dalam hubungan dengan pawongan, palemahan, dan parahyangan. Pitana (Budiana, 2004 : 221) menyatakan bahwa desa pakraman harus mampu menjadi wahana pengembangan berbagai nilai positif yang ada pada kebudayaan Bali, seperti nilai demokrasi, toleransi, adaptasi, kreativitas, fleksibilitas, dan sebagai wahana eliminasi berbagai tradisi yang tidak sesuai dengan perkembangan zaman. Desa adat (desa pakraman) sebagai institusi yang mengatur tatakrama masyarakat Bali harus mampu memilah dan memilih tradisi yang perlu dikembangkan dan tradisi yang ditinggalkan. Akan tetapi dewasa ini tradisi di Bali yang masih menunjukkan ketidakemasipasian. Salah satu di antaranya jika terjadi perkawinan antarwangsa. Hobart (1980 : 109-110) menyatakan bahwa sejumlah individu yang melakukan perkawinan antawangsa masih memperlihatkan ketidakemansipasian karena mendapat perlakuan diskriminatif pada saat ritual perkawinan. Pada saat ritual perkawinan, mempelai perempuan yang wangsanya lebih rendah (sudra wangsa) tidak langsung bersanding dengan mempelai laki-laki triwangsa, tetapi dengan sebilah keris milik memepelai laki-laki atau digantikan dengan tiang rumah (adegan) yang sudah dihias dengan pakaian pengantin laki-laki. Sudarma (2012 : 261 ) dalam disertasi berjudul "Perkawinan Nyeburin di Tengah Perubahan Sosial di Kabupaten Tabanan" menyatakan bahwa ketidakemasipasian perkawinan antarwangsa terutama pada perkawinan nyeburin, yaitu kedua mempelai dan keluarga dikeluarkan dari kerabatnya, dan dilarang sembahyang di tempat suci milik keluarga besarnya. Dewasa ini sanksi keluarga tersebut tergolong berat karena bertentangan dengan nilai-nilai kemanusiaan, dan ajaran agama.

Perkawinan eksogami di Desa adat Tenganan Pegringsingan sampai saat ini masih menunjukkan ketidakemansipasian. Ketidakemansipasian itu tampak pada penerapan sanksi adat bagi warga yang melakukan perkawinan eksogami. Walaupun sanksi adat pada perkawinan eksogami bertentangan dengan ajaran agama dan nilai-nilai kemanusiaan, warga takut melawan norma-norma dan nilai-nilai budaya masyarakatnya. Dengan demikian, warga selalu dihadapkan pada masalah yang sulit jika melakukan perkawinan eksogami.

Sanksi perkawinan antarwangsa hampir sama dengan perkawinan antarwarga berbeda adat di Desa Adat Tenganan Pegringsingan. Perkawinan antarwangsa dan perkawinan eksogami di desa ini sama-sama diberikan sanksi. Akan tetapi dalam dekade belakangan ini di Bali, sanksi perkawinan antarwangsa jauh lebih ringan daripada perkawinan eksogami. Sanksi perkawinan antarwangsa biasanya berupa pengucilan mempelai dan orang tuanya dari keluarganya sendiri, tetapi masih memiliki hak sebagai warga masyarakat dan 
untuk tinggal di desanya. Sebaliknya, perkawinan eksogami di Desa Adat Tenganan Pegringsingan mengakibatkan semua hak dicabut. Pencabutan semua hak berarti mempelai sama sekali tidak memiliki hak lagi di desanya. Penjatuhan sanksi dalam perkawinan eksogami penting dilakukan untuk menjaga dan mempertahankan tradisi perkawinan endogami di desanya. Tanpa sanksi, warga masyarakat akan mengabaikan larangan pada perkawinan eksogami. Putra (2015 : 324325) mengemukakan bahwa pemberian sanksi dimaksudkan untuk mengembalikan kesucian dan keseimbangan desa dari keletehan (keadaan tidak suci).

Penerapan sanksi adat pada perkawinan eksogami di Tenganan Pegringsingan telah menunjukkan ketidakemansipasian. Warganya yang melakukan perkawinan eksogami tidak mendapatkan perlindungan karena semua hak dicabut oleh desa. Wertheim (Wisnumurti, 2010 : 369) mengatakan bahwa emansipasi berkaitan dengan pembebasan manusia dari alam sekeliling, kebebasan potensi-potensi kreatif manusia dari struktur-struktur masyarakat yang mencekik teristimewa dari kemusnahan. Di samping itu, juga pembebasan manusia dari bentuk-bentuk penguasaan dan perbudakan yang membelenggu yang diciptakan oleh manusia sendiri. Penerapan sanksi adat dalam perkawinan eksogami di Tenganan Pegringsingan juga bertentangan dengan Undang-Undang Republik Indonesia No. 39, Tahun 1999 tentang Hak-hak Asasi Manusia yang termuat pada pasal 3 ayat 3, dan pasal 4 sebagai berikut.

Pasal 3 ayat 3 memuat bahwa setiap orang berhak atas perlindungan hak asasi manusia dan kebebasan dasar manusia tanpa diskriminasi.

Pasal 4 memuat bahwa setiap orang memiliki hak untuk hidup, hak untuk tidak disiksa, hak untuk kebebasan pribadi, pikiran dan hati nurani, hak beragama, hak untuk tidak diperbudak, hak untuk diakui secara pribadi dan persamaan di hadapan hukum adalah hak asasi manusia yang tidak dapat dikurangi dalam keadaan apa pun dan oleh si apa pun (Anonim, $2016: 4-5$ ).

Kutipan di atas menunjukkan bahwa perkawinan antarwarga berbeda adat di Tenganan Pegringsingan mencerminkan ketidakemansipasian. Pelanggaran atas perkawinan eksogami menyebabkan semua hak dicabut oleh desa. Pencabutan semua hak berarti mereka sama sekali tidak memiliki hak termasuk hak untuk tinggal di desanya.

\subsection{Tidak Memperoleh Kesejahteraan dari Desa Adatnya}

Pelanggaran atas larangan perkawinan eksogami menyebabkan kedua mempelai tidak memperoleh kesejahteraan dari desa adat. Setiap manusia memiliki berbagai kebutuhan hidup, lebih-lebih sesudah melakukan perkawinan. Menurut ajaran agama Hindu, perkawinan adalah sebuah yadnya (korban suci). Perkawinan sebagai awal untuk menuju masa grehasta, yaitu masa yang paling penting dalam kehidupan manusia. Setiap orang yang akan melaksanakan perkawinan harus menyadari arti dan hakikatnya. Di dalam grehasta, ada tiga perilaku yang harus dilaksanakan, yaitu dharma, artha, dan kama. Dharma adalah aturanaturan yang berkaitan dengan dharma agama dan negara. Artha adalah kebutuhan hidup berumah tangga untuk mendapatkan kesejahteraan berupa materi dan pengetahuan. Kama adalah rasa kenikmatan yang diperoleh dalam keluarga sesuai dengan ajaran agama (Artayasa, dkk, 1998:4-5) .

Dalam kitab Manawa Dharma Sastra dimuat bahwa perkawinan memiliki tiga tujuan, yaitu (1) dharma sampati (bersama-sama suami istri mewujudkan pelaksanaan dharma), (2) praja (melahirkan keturunan), dan (3) rati (menikmati kehidupan seksual dan kepuasan lainnya). Dari ketiga tujuan perkawinan tersebut, praja menempati kedudukan yang penting dalam keluarga karena dengan melahirkan putra-putri yang suputra dapat menyelamatkan para leluhur dari neraka. Keluarga yang dikaruniai keturunan yang baik akan membawa leluhurnya pada kondisi 
yang lebih baik, yaitu leluhurnya akan dapat mencapai surga atau moksa (Suja, 1999 : 4-57).

Perkawinan dilaksanakan tidak hanya sekadar hubungan biologis, tetapi identik dengan yadnya samkara, yaitu perkawinan dan segala akibatnya bernilai suci, terutama membersihkan atau menyucikan sukla swanita (bibit) kedua mempelai. Perkawinan juga menyangkut jasmani/ lahiriah, dan batin/rohaniah. Ikatan lahir batin bermakna kemanunggalan antara sekala (di dunia nyata) dan niskala (di dunia tidak nyata). Tuhan memanfaatkan perkawinan untuk menciptakan manusia dalam kitab Bhagawadgita III. 10 dinyatakan sebagai berikut.

\section{"Sahajná prajah srița pura ẃaca prājap- atih}

Anena prasawisya dhiwam esa ẃa stiwisịta kāmaduk"

\section{Terjemahannya :}

Sesungguhnya sejak dahulu dikatakan bahwa Tuhan telah menciptakan manusia melalui yadnya dengan (cara) ini engkau akan berkembang, sebagai lembu perahan yang memerah susunya karena keinginanmu sendiri (Pudja,1985:76).

Kutipan di atas menunjukkan bahwa Tuhan telah menciptakan manusia agar berkembang. Manusia bisa berkembang hanya melalui perkawinan.

Wiana (2006:45) menyatakan bahwa sesorang bisa dikatakan hidup sejahtera jika kebutuhan hidupnya terpenuhi. Kebutuhan yang dimaksud, yaitu (1) kebutuhan biologis adalah kebutuhan akan sandang, pangan, papan, dan kesehatan. (2) kebutuhan sosial adalah kebutuhan untuk dapat menerima dan diterima dalam pergaulan hidup di masyarakat, dan (3) kebutuhan filosofis adalah kebutuhan akan pendidikan dan kebudayaan di dalamnya termasuk hidup beragama. Salah satu di antara ketiga kebutuhan tersebut, yaitu kebutuhan akan sandang, pangan, papan, dan kesehatan sangat diperlukan oleh masyarakat Tenganan Pegringsingan. Kebutuhan tersebut akan bisa diraih dari desanya jika warga melakukan perkawinan endogami sesama warga desanya sendiri. Sebaliknya, kesejahteraan mempelai praktis hilang jika warganya melakukan perkawinan eksogami. Dengan demikian, kedua mempelai harus berhati-hati dalam melakukan perkawinan jika masih ingin tetap memperoleh kesejahteraan dari desanya.

Desa Tenganan Pegringsingan merupakan sebuah desa kuno di Bali yang masih kental dengan tradisi perkawinan endogami desa. Jika kedua mempelai ingin memperoleh kesejahteraan dari desa adatnya, warga harus melakukan perkawinan endogami. Tanpa perkawinan ini praktis kesejahteraan mempelai hilang walaupun perkawinan bernilai sakral dan memiliki tujuan yang mulia, dilakukan sama-sama saling mencintai, dan tidak melanggar undang-undang perkawinan di Indonesia. Kesejahteraan dalam perkawinan di Desa Adat Tenganan Pegringsingan hanya bisa diperoleh melalui perkawinan endogami sesama warga adatnya sendiri. Kesejahteraan berasal dari kata "sejahtera" artinya aman santosa dan makmur, selamat (terlepas dari segala macam gangguan), kesukaran, dan sebagainya. Kata "sejahtera" mendapat awalan "ke" dan akhiran "an" sehingga menjadi kesejahteraan artinya keamanan, keselamatan, ketenteraman, kesenangan hidup, dan kemakmuran (Tim Penyusun, 1993 :794).

Timur sebagai warga Tenganan Pegringsingan menyatakan bahwa perkawinan sangat menentukan bisa tidaknya mempelai memperoleh kesejahteraan dari desanya. Ketentuan mendapatkan kesejahteraan dari desanya jika warga melakukan perkawinan endogami. Kesejahteraan mempelai tidak hanya berupa beras, tetapi juga uang yang diperoleh dari aset-aset milik desa, seperti hasil subak, pendapatan dari pariwisata, hasil sawah, dan hasil kebun. Pembagian kesejahteraan dilakukan secara rutinitas per bulan, dan secara insidental pada saat upacara ngusabha sambah. Kesejahteraan yang diberikan disesuaikan dengan jabatan pada struktur sosial, yaitu Luwanan mendapat bagian beras 100 $\mathrm{kg} /$ bulan dan uang Rp 2.000.000,00 sedangkan 
pada saat Usabha Sambah mendapat bagian beras $300 \mathrm{~kg}$, dan uang sebesar Rp 3.000.000 (tiga juta rupiah); Bahan Roras (Bahan Duluan/Keliang Desa dan Bahan Tebenan) masing-masing mendapat bagian beras $100 \mathrm{~kg} /$ bulan, dan beras 250 kg serta uang Rp. 2,500.000,00 pada saat upacara ngusabha sambah; Tambalapu Roras, mendapat bagian beras $100 \mathrm{~kg} / \mathrm{bulan}$, dan saat ritual usabha sambah mendapat bagian beras $250 \mathrm{~kg}$, dan uang Rp 2,500.000,00; Pengeluduan, mendapat bagian beras $100 \mathrm{~kg} / \mathrm{bulan}$, dan beras $300 \mathrm{~kg}$ serta uang Rp 3.000.000,00 ketika ritual ngusabha sambah. Dengan ketentuan tersebut, mempelai harus hati-hati melaksanakan perkawinan karena hal itu menentukan berhak tidaknya mempelai memperoleh kesejahteraan dari desa adatnya.

\subsection{Kehilangan Hak di Desa Adat}

Dalam kehidupan bermasyarakat, manusia mempunyai cara-cara tetentu mengatur hubungan antara hidup dan kehidupan. Dalam hubungan tersebut diperlukan aturan-aturan yang didasarkan atas nilai-nilai mengenai apa yang dianggap baik atau tidak patut. Aturan-aturan itu merupakan patokan mengenai apa yang boleh diperbuat sehingga aturan-aturan itu membatasi sikap, tingkah laku, dan perbuatan manusia yang satu dengan manusia yang lainnya. Aturanaturan kemasyarakatan hidup, berkembang dan diterima sebagai suatu keharusan karena mereka menganggap penting adanya suatu pembatasan. Kehidupan yang bebas tanpa batas tidak dikenal di dalam kehidupan bermasyarakat. Dengan demikian, setiap masyarakat merasa terikat dalam suatu kehidupan bermasyarakat. Di samping itu mereka sangat memerlukan adanya pembatasan demi terciptanya kehidupan yang tertib, aman dan damai (Majelis Pembina Desa Adat Daerah Tk. I Bali, 1992/1993 : 19).

Di Bali terdapat dua organisasi desa yang berbeda secara substansial dan fungsional, yaitu desa adat dan desa dinas. Tiap-tiap desa ini mempunyai struktur dan fungsi sendiri sehingga keterikatan anggota masyarakat kepada kedua organisasi ini berbeda. Raka (1955:19) menyatakan bahwa desa adat adalah suatu kesatuan wilayah yang warganya secara bersamasama mengonsepsikan dan mengaktifkan upacara keagamaan untuk memelihara kesucian desa. Rasa kesatuan sebagai warga desa adat terikat karena adanya karang desa (wilayah teritorial), awig-awig desa adat (sistem aturan desa dengan peraturan pelaksanaannya), dan Pura Khayangan Tiga (tiga pura di desa sebagai system tempat persembahyangan bagi warga desa adat).

Kehidupan sosial budaya masyarakat Bali teroganisasi dalam orgnisasi sosial yang disebut dengan desa adat atau desa pakraman. Desa adat pada zaman Bali kuno disebut banwa atau banua (Goris, 1954:59). Covarrubias (1986:56) mengemukakan bahwa desa adat merupakan kesatuan wilayah tertutup atau terbatas pada pemujaan leluhur dan peraturan administrasi masyarakat. Tiap-tiap desa adat dilengkapi dengan unsur-unsur kesatuan pura (tempat suci) sebagai pengikat sebuah desa, yaitu khayangan tiga (Pura Desa, Pura Puseh, Pura Dalem). Senada dengan Covarrubias, Suputra menyatakan bahwa desa adat mencakup dua hal, yaitu desa adat sebagai wadah dan adat istiadat sebagai isi dari wadah. Desa adat sebagai lembaga tradisional mewadahi kegiatan sosial, budaya, dan keagamaan masyarakat Hindu di Bali, sedangkan adat istiadat adalah tata krama kehidupan masyarakat umat Hindu di Bali yang telah menjadi tradisi kemasyarakatan sebagai warisan budaya bangsa (Wisnumurti, 2010:175-176).

Setiap desa pakraman (desa adat) di Bali termasuk Desa Adat Tenganan Pegringsingan memiliki aturan tertulis maupun tidak tertulis, yang disebut dengan awig-awig desa adat. Awigawig merupakan peraturan atau ketentuan dasar yang dibuat oleh krama (warga) desa adat yang dijadikan pedoman perilaku mereka. Awigawig juga mengarahkan dan mengatur polapola perilaku krama desa adat untuk mencapai 
ketertiban dan kehidupan bermasyarakat serta menjadi pedoman menyelesaikan sengketa baik di antara sesama krama desa adat maupun krama desa adat dengan desa adat. Awig-awig juga merupakan penjabaran kongkret dari tri hita karana yang mengatur empat hal utama, yaitu (1) tata sukerta parahyangan, yaitu aturan dan ketentuan yang menjadi dasar atau pedoman perilaku hubungan krama desa adat dengan Hyang Widi (Tuhan). (2) tata sukerta pawongan, yaitu aturan dan ketentuan yang menjadi dasar atau pedoman perilaku hubungan antara sesama krama desa adat, baik hubungan vertilal maupun horizontal dalam kehidupan bermasyarakat. (3) tata sukerta palemahan, yaqitu aturan dan ketentuan yang menjadi dasar atau pedoman perilaku hubungan krama desa adat dengan alam sekitarnya, dan (4) sanksi bagi krama adat yang melanggar awig-awig dengan pasuarannya (peraturan pelaksanaan) (Gorda, 1999 : 10-11).

Dalam bahasa Bali awig-awig berasal dari kata "wig". Kata "wig" lazim disebut dengan istilah "uig" artinya terlalu memilih, suka mengganggu. Nguig artinya suka mengganggu. Da demen nguig timpal artinya jangan senang mengganggu teman (Tim Penyusun, 2008 :776). Kata "wig" kemudian mendapat nasalisasi "a" sehingga menjadi awig yang berarti tidak rusak. Astiti (2005:19) meyatakan bahwa awig-awig adalah patokan-patokan tingkah laku, baik tertulis maupun tidak tertulis yang dibuat oleh masyarakat bersangkutan berdasarkan keadilan dan kepatutan yang hidup dalam masyarakat dalam hubungan krama (warga) desa dengan Tuhan, antar krama, dan antara krama dengan lingkungannya.

Awig-awig desa adat disusun oleh krama adat melalui sangkepan (rapat) desa adat. Awig-awig yang telah ditetapkan oleh sangkepan desa adat, sebelum diberlakukan kepada seluruh masyarakat, terlebih dahulu dilakukan upacara pengesahan secara adat keagamaan yang disebut upacara pasupati. Upacara ini diselenggarakan pada salah satu pura tri khayangan tiga milik desa adat yang bersangkutan. Upacara pengesahannya dihadiri oleh seluruh masyarakat adat dan disaksikan oleh aparatur Pemerintah daerah. Upacara pasupati bermakna memberikan kekuatan sakral dan kekuatan frofan terhadap awig-awig desa adat. Dengan demikian, awig-awig desa adat di Bali tidak hanya memiliki kekuatan berupa ganjaran-ganjaran dan hukuman-hukuman yang bersifat duniawi dan manusiawi (profan), tetapi juga memiliki ganjaran dan hukuman yang beresifat supramanusiawi dan sorgawi (sakral). Durkheim menyatakan bahwa adanya sanksi yang bersifat sakral dan profan lebih memperkuat ketaatan, kepatuhan, dan keyakinan anggota masyarakat terhadap nilai-nilai, norma-norma dan aturan-aturan yang berlaku di masyarakat (Gorda, 1999:11-12).

Surpha (2002:56-57) mengemukakan bahwa tiap-tiap anggota desa adat memiliki berbagai kewajiban dan hak. Kewjiban-kewajiban yang dimaksud meliputi (1) wajib melaksanakan ayahan desa (tugas krama desa) berupa kerja bakti memperbaiki/membangun pura milik desa adat, melaksanakan upacara dewayajña, menyelenggarakan upacara bhutayajña setiap tilem kesanga, melaksanakan upacara makiyis, melaksnakan pembangunan untuk desa adat, dan sebgainya; (2) wajib mentaati aturan-aturan yang berlaku di desa adatnya; (3) wajib menjaga keamanan dan ketentraman bersama; (4) menjaga nama baik desanya dan melaksanakan sukaduka (gotong royong) antara sesama. Sebaliknya, hakhaknya, yaitu berhak mengeluarkan pendapat dalam sangkepan (rapat), berhak menggunakan fasilitas milik desa pakraman, berhak minta bantuan untuk menyelenggarakan upacara agama, dan berhak mendapat bantuan dalam keadaan bahaya, dan sebagainya. Adanya sejumlah hak dan kewajiban memungkinkan krama desa saling mendukung dalam mengaktifkan suatu kegiatan di desa adat.

Jika di antara krama (anggota) desa pakraman menyimpang dari berbagai kewajiban yang tertera pada awig-awig desa adat, dia akan dijatuhi sanksi adat. Tanpa sanksi, awig- 
awig tidak memiliki wibawa untuk ditaati oleh masyarakat. Van Vollenhoven merumuskan hukum adat sebagai peraturan adat istiadat yang ada sanksinya dan mengandung paksaan. Soepomo, Ter Haar, Lesquiller (Dharmayuda, 2001:36-37) mengatakan bahwa sanksi adat adalah bentuk tindakan atau usaha-usaha untuk mengembalikan keseimbangan termasuk keseimbangan magis akibat adanya gangguan pelanggaran adat.

Kalangan peneliti barat menganggap hukum adat bersifat unik dan khas. Sifat uniknya tampak pada pembauran antara gejala hukum kasat mata dan alam hukum suprarnatural (gaib). Hal itu menyebabkan F.D Hollemen memandang corak utama hukum adat adalah "magisch religieus" artinya hukum adat selalu berhubungan dengan unsur-unsur keagamaan penduduk dan kepercayaan yang sakral. Di pihak lain, sifat khasnya terpancar dari alam pikiran yang menjadi dasar substansi norma hukum adat yang dilandasi oleh pikiran berpartisipasi. Artinya, apa pun di dunia ini adalah saling kait mengait. Dengan demikian, setiap orang harus mengusahakan hubungan harmonis dengan berbagai unsur di luar dirinya. Manusia harus selalu hidup rukun dengan sesama, dengan lingkungan alamnya untuk menciptakan keseimbangan melalui saling memberi dan menerima (Dharmayuda, 2001:55).

Desa Tenganan Pegringsingan, Karangasem Bali sampai saat ini masih menerapkan larangan pada perkawinan eksogami. Sebaliknya, perkawinan yang dianjurkan dan diharapkan adalah endogami desa yang terjadi sesama warga adatnya sendiri. Perkawinan endogami akan menentukan status sebagai krama desa, yakni warga yang memiliki hak untuk mengikuti sangkep (rapat) di Bale Agung. Rapat dilakukan untuk mengambil keputusan-keputusan di desa adat. Jika perkawinan dilakukan secara eksogami, haknya praktis hilang. Hak untuk mengikuti sangkepan sangat istimewa karena dapat menghasilkan keputusan-keputusan yang menentukan perkembangan desa dan mendapat bagian dari hasil perolehan aset-aset desa (Sujaya, 2007 : 39-40).

Yudiana meyatakan bahwa masyarakat Desa Tenganan Pegringsingan memiliki tiga macam krama, yaitu krama desa, krama gumi pulangan, dan krama gumi. Krama desa adalah anggota masyarakat yang paling istimewa daripada anggota masyarakat yang lainnya. Keistimewaannya ditunjukkan bahwa hanya mereka yang berhak duduk dalam struktur sosial, ikut dalam sangkepan, mendapat bantuan kesehatan dan pembagian hasil aset-aset desa. Krama gumi pulangan adalah krama yang tidak memiliki hakhak istimewa lagi. Jika anaknya menikah, praktis hak istimewanya digantikan oleh anaknya yang baru menikah. Denagan pengambilalihan hak istimewanya, hak sebagai krama desa hilang. Di pihak lain, krama gumi adalah krama yang telah menjadi duda atau janda. Krama ini tidak berhak ikut dalam struktur sosial, dan dalam sangkepan. Perlu dikemukakan bahwa krama gumi pulangan masih bisa mendapatkan kesejahteraan atas dasar kebijakan desanya, sedangkan krama gumi sama sekali tidak memperoleh pembagian yang bersumber dari kekayaan desa. Maksudnya, mereka hanya menikmati harta warisan dan hasil usahanya sendiri.

Struktur sosial Desa Adat Tenganan Pegringsingan terdiri atas luwanan, bahan roras, tambalapu roras, dan pengeluduan. Luwanan adalah jabatan yang teratas yang anggotanya terdiri atas enam pasang yang bertugas sebagai penasihat dalam pemerintahan. Bahan duluan/bahan roras adalah jabatan yang bertugas sebagai pengambil keputusan dalam pemerintahan. Keliang desa adalah jabatan untuk melaksanakan pemerintahan desa sehari-hari. Tambalapu roras, yaitu jabatan yang bertugas menyampaikan perintah keliang desa. Pengeluduan adalah jabatan khusus sebagai membantu keliang desa dalam mencari perlengkapan sarana upacara keagamaan. Struktur sosial krama desa di Desa Pakraman Tenganan Pegringsingan adalah sebagai berikut. 
Luwanan Ungguan Krama desa dalam struktur sosial di Tenganan Pegringsingan harus dalam keadaan utuh, yang disebut dengan bulu angkep (suami-istri yang utuh). Keikutsertaan mereka dalam struktur sosial didasarkan sistem ulu apad (senioritas), yaitu waktu perkawinan. Pasangan mempelai yang lebih dahulu kawin dianggap lebih senioritas dan berkedudukan lebih tinggi daripada mereka yang kawin belakangan. Kedudukan krama desa dalam struktur sosial di Desa Adat Tenganan Pegringsingan secara keseluruhan adalah sebagai berikut.

(1) Lima orang yang disebut luwanan, yaitu krama No. 1 sampai dengan No. 5 menempati kedudukan paling atas dalam struktur sosial.

(2) Enam orang yang disebut bahan duluan, yaitu krama yang dimulai dari no. 1- 6 yang bertugas sebagai keliang desa .

(3) Enam orang yang disebut bahan tebenan, yaitu krama yang dimulai dari nomor 7- 12 sebagai calon pengganti keliang desa dan membantu bahan duluan.

(4) Dua belas orang yang disebut tambalapu roras, yaitu krama yang dimulai dari nomor 1 sampai nomor 12 yang bertugas menyampaikan perintah keliang desa secara bergilir setiap satu bulan sekali oleh empat orang anggotanya.

(5) Krama desa pakraman dari nomor 1 berikutnya sampai habis yang disebut pengeluduan bertugas membantu keliang desa mencari perlengkapan sarana upacara keagamaan.

Mereka yang menempati posisi sebagai kliang desa, diwajibkan berkumpul tiap malam di Bale Agung untuk membahas segala permasalahan yang belum terpecahan di desanya. Jika salah seorang anggota keliang desa yang laki-laki berhalangan hadir, bisa diwakili oleh istrinya. Jika permasalahan juga belum dapat diselesaikan, akan diadakan sangkepan atau pertemuan desa lagi. Sangkepan ini hanya dihadiri oleh krama desa muani (anggota desa laki-laki) untuk membahas permasalahan yang belum dapat diselesaikan.
Jika sangkepan juga tidak mencapai kesepakatan, rapat digelar kembali dengan mengundang kliang gumi dan semua krama desa bulu angkep (pasangan suami istri). Semua pasangan suami istri mempunyai hak yang sama, dan pengambilan keputusan dilakukan dengan voting.

Adanya perlakuan diskriminasi antara perkawinan endogami dan eksogami, dan khawatir akan kehilanghan hak menyebabkan orang tua selalu menasehati anaknya agar tidak melakukan perkawinan eksogami. Pelanggaran atas larang perkawinan eksogami menyebabkan semua hak dicabut oleh desanya. Dengan pencabutan semua hak, praktis kedua mempelai tidak memiliki hak tidak hanya sebagai sebagai krama desa, tetapi juga krama gumi pulangan.

\section{Simpulan}

Masyarakat Desa Adat Tenganan Pegringsingan masih kental dengan tradisi perkawinan endogami antar sesama warga adatnya sendiri. Perkawinan ini dianggap sebagai model perkawinan yang ideal dan terhormat. Sebaliknya, perkawinan eksogami dilarang dan dikenai sanksi adat. Sanksi tidak hanya dijatuhkan kepada kedua mempelai, tetapi juga kepada orang tuanya.

Alasan-alasan sanksi adat pada perkawinan eksogami, yaitu melestarikan tradisi, menjaga sistem kekerabatan, dan menjaga keseimbangan. Dalam konteks melestarikan tradisi, sanksi adat digunakan untuk menjaga dan memelihara serta melestarikan perkawinan endogami sebagai model perkawinan yang paling ideal dan terhormat. Dengan melestarikan tradisi, keaslian unsur-unsur kebudayaan, khususnya perkawinan endogami sesama warga adat tidak punah. Dalam konteks kekrabatan, sanksi adat digunakan untuk menjaga dan mempertahankan kemurnian sistem kekerabatan bilateral di desa adat. Dengan kekerabatan ini, kedua mempelai sama-sama setara kedudukannya di mata hukum. Artinya, kedua memepelai mempunyai hak yang sama sebagai ahli waris. Dalam konteks keseimbangan, sanksi 
adat dalam perkawinan eksogami digunakan untuk menjaga keseimbangan tri hita karana, yaitu parahyangan, pawongan, dan palemahan. Perkawinan eksogami dianggap telah membawa keletehan sehingga keseimbangan Desa Adat Tenganan Pegringsingan terganggu.

Bentuk sanksi adat pada perkawinan eksogami ada dua macam, yaitu sanksi denda dan sanksi moral. Terkait dengan sanksi denda, orang tua mempelai harus membayar uang dengan nominal Rp18 000,0. Orang tua mempelai juga harus membayar uang tiap bulan Rp1000,00 selama hidupnya. Dalam konteks sanksi moral, kedua mempelai dan orang tuanya terbebani secara batin karena perkawinan yang dilakukan merupakan perkawinan yang terlarang. Pelanggaran atas larangan perkawinan tersebut menyebabkan keletehan di desa adat. Mempelai dan orang tuanya harus menanggung rasa malu selama hidupnya karena telah menyebabkan kecemaran desa adat.

Sanksi adat pada perkawinan eksogami menunjukkan ketidakemansipasian, tidak memperoleh kesejahteraan dari desa adatnya, dan kehilangan semua hak-haknya di desanya. Dalam konteks ketidakemansipasian, warga Desa Adat Tenganan Pegringsingan tidak diperbolehkan melakukan perkawinan dengan warga diluar desa adatnya. Pelanggaran atas larangan perkawinan eksogami dikenai sanksi adat. Dalam konteks tidak memperoleh kesejahteraan dari desa adat, warga yang melakukan perkawinan eksogami tidak berhak menerima kesejahteraan dari desa adat. Dengan perkawinan eksogami, semua hak mempelai dicabut termasuk hak untuk memperoleh pembagian hasil dari desa adat. Dengan pencabutan ini praktis mempelai tidak mendapatkan kesejahteraan. Dalam konteks kehilangan semua hak di desanya, yaitu warganya yang melanggar laragan perkawinan eksogami menyebabkan semua hak dicabut sehingga mempelai sama sekali tidak memiliki hak di desanya atau tidak dianggap warga lagi.

\section{DAFTAR PUSTAKA}

Al-Barry, M Dahlan Yacub. 2001.Kamus Sosiologi Antropologi. Surabaya : Indah

Andreski, Stainlav. 1996. Marx Weber : Kapitalisme, Birokrasi dan Agama. Cetakan Kedua. Yogyakarta : Tiara Wacana.

Anonim. 2016. Undang-Undang HAM 1999. Jakarta : Sinar Grafika

Artayasa, I Nyoman dkk. 1998. Petunjuk Teknis Perkawinan Hindu. Surabaya : Paramita.

Budiana, I Nyoman. 2004. "Rekonstruksi Perkawinan Eksogami di Tengah Perubahan Sosial di Bali”. Disertasi. Surabaya : Program Pascasarjana Universitas Airlangga.

Budiana, I Nyoman. 2008. Perkawinan Beda Wangsa dalam Masyarakat Bali. Yogyakarta : Graha Ilmu.

Calyton, Richard. R. 1975. The Family, Marriage and Social Change. Lexington, Massachusetth, Toronto, London : D.C. Health and Company.

Covarrubias, Miguel. 1986. Island of Bali. New York : Knopf

Covarrubias, Miguel. 2013. Pulau Bali. Diterjemahkan oleh Sunaryo Basuki Ks. Denpasar : Udayana University Press

Desa Adat Tenganan Pegringsingan, tt. Awig-awig Desa Tenganan Pegringsingan

Dharmayudha, I Made Suasthawa. 2001. Peranan Desa Pakraman dalam Menyelesaikan Kasus Adat. Denpasar : Biro Hukum Setda Propinsi Bali

Dharmayudha, I Made Suasthawa. dan Çantika, I Wayan Koti. 1991. Filsafat Adat Bali. Denpasar. Upada Sastra.

Diputra, Dharma Dewa I.B.N. 2003. "Pola Penyelesaian Perkawinan Nyeburin Berbeda Wangsa di Wilayah Pemerintah Kabupaten Tabanan". Tesis. Semarang : Program Magister Kenotariatan Universitas Diponogoro. 
Friederich, R. 1959. The Civilization and Culture of Bali, Edited by Ernst R.Rost, Susil Gupta (India), Private Ltd

Geertz, Hildred \& Geertz, Clifoford. 2017. Sistem Kerabatan di Bali. Penerjemah Prof. Dr. IDK Harya Putra.

Gorda, I Gusti Ngurah. 1999. Manajemen dan Kepemimpinan Desa Adat di Propinsi Bali dalam Perspektif Globalisasi. Denpasar :Widya Kriya Gematama.

Goris, R. 1954. Inscripties voor Anak Wungsu dalam Prasasti Bali. Jakarta : N.V.Masa Baru

Hobart, Mark. 1980. Ideas of Identity: The Interpretation of Kinship in Bali. Denpasar : Jurusan Antropologi Fakultas Sastra UNUD

Kaler, I Gusti ketut. 1983. Butir-Butir Tercecer Tentang Adat Bali. Jilid 2. Denpasar : Bali Agung

Koentjaraningrat, 1992. Antropologi Sosial. Jakarta. Dian Rakyrat.

Korn, V.E. 2017. Hukum Adat di Bali (Het Adatrecht Van Bali). Jilid 2. Penerjemah Mean Joebaar dan I Nengah Merta. Denpasar : Udayana University Press.

Majelis Pembina Lembaga Adat Derah Tingkat I Bali. 1992/1993. Desa Adat dan Kepariwisataan di Bali. Denpasar : Proyek Pemantapan Lembaga Adat

Maswinara, I Wayan. 1997 . Bhagawad Gita. Surabaya : Paramita.

Oka, I Gusti Agung, 1992. Slokantara. Jakarta.: Hanuman Sakti.

Polomo, Margareth M. 1992. Sosiologi Kontemporer. Jakarta: Rajawali Press.

Projodikoro, Wiryono R. 2000. Perbuatan Melanggar Hukum. Bandung : Mandar Maju

Putra, Sudarma Ida Bagus. 2015. Hakikat Sanksi Adat Sangaskara Danda terhadap Pelanggaran Adat Gamia Gamana. Jurnal Magister Hukum Adat volume 4, No.2 Hal.205-424 Denpasar Bali Juli 2015, ISSN 2302-528X : Program Studi Magister
(S2) Ilmu Hukum Program Pascasarjana Universitas Udayana.

Saderson, Stephen K, 1993. Sosiologi Makro (Sebuah PendekatanTehadap Sosialitas Sosial), Cetakan Pertama. Jakarta : Rajawali Press.

Sianturi, S.R.1986. Azas-Azas Hukum Pidana Di Indonesia Dan Penerapannya.Jakarta : Alumni Ahaem-Petehaem.

Sudarma, I Putu. 2012. Perkawinan Nyeburin Di Tengah Perubahan Sosial Di Kabupaten Tabanan. Disertasi. Denpasar : Program Pascasarjana Universitas Udayana.

Sudarma, I Putu. 2015. "Bias Gender dalam Perkawinan Bedawangsa pada Masyarakat Hindu Bali". Jurnal Harmoni No. 3 volome14 September-Dember 2015. Issn 1412-663 X. Jakarta:Puslitbang kehidupan Keagamaan Badan Litbang dan Diklat Kementerian Agama RI.

Suja, I Wayan. 1999. Tafsir Keliru terhadap Hindu. Denpasar : Yayasan Dharma Naradha Sujaya. I Made. 2007. Perkawinan Terlarang. Denpasar. Widya Pataka

Surpha, I Wayan. 2002. Seputar Desa Pakraman Dan Adat Di Bali. Denpasar : PT. Ofsset BP.

Ter Haar, Mr. B. 2001. Azas-Azas dan Susunan Hukum Adat. Terjemahan Soebakti Poesponoto. Jakarta : Pradnya Paramita.

Tim Penyusun. 1989/1990 : Mengenal dan Pembinaan Desa Adat di Bali. Denpasar : Proyek Pemantapan Lembaga Afat Tersebar di 8 (delapan) Kabupaten Dati II Tahun Anggaran 1989/1990.

Tim Penyusun. 1993. Kamus Besar Bahasa Indonesia. Jakarta. Balai Pustaka.

Tim Penyusun. 2005. Dialog Ajeg Bali. Surabaya : Paramita.

Tim Penyusun. 2010. Wicara Lan Pamidanda. Denpasar. University Press.

Titib, I Made.2003. Menumbuhkembangkan Pendidikan Budhi Pekerti pada Anak : 
Perpektif Teologi Hindu. Jakarta : Parisadha Hindu Dharma Indonesia Pusat.

Wiana, I Ketut 2006. Memahami Perbedaan Catur Warna, Kasta dan Wangsa. Surabaya : Paramita.

Wiana, I Ketut. 2007. Tri Hita Karana Menurut Konsep Hindu. Surabaya : Paramita

Widnyana, I Made. 1993.Kapita Selekta Hukum Pidana Adat. Bandung : Eresco.

Windia .2003. Danda Pacamil. Denpasar : Upadasastra

Windia. 2008. Bali Mawacara. Denpasar : Udayana University Press Wisnumurti, Anak Agung Gede Oka. 2010. "Dinamika Politik Lokal dalam Pemilihan Kepala Daerah Langsung 2005 di Kabupaten Badung” Disertasi. Denpasar : Program Pascasarjana Universitas Udayana. 